\title{
Comparative Study of the Electrical Characteristics of Different Photovoltaic Modules in Outdoor Environment
}

\author{
Abdul Rehman Jatoi \\ Energy and Environment Engineering \\ Department, Quaid-e-Awam University \\ of Engineering, Science and Technology, \\ Nawabshah, Pakistan \\ arjatoi@quest.edu.pk
}

\author{
Saleem Raza Samo \\ Energy and Environment Engineering \\ Department, Quaid-e-Awam University \\ of Engineering, Science and Technology, \\ Nawabshah, Pakistan \\ sfaizsamo@yahoo.com
}

\author{
Abdul Qayoom Jakhrani \\ Chemical Engineering Department, \\ Quaid-e-Awam University of \\ Engineering, Science and Technology, \\ Nawabshah, Pakistan \\ aqbaloch@quest.edu.pk
}

\begin{abstract}
The electrical characteristics of photovoltaic (PV) modules are affected by solar radiation and module temperature in outdoor environment. It was found that polycrystalline gained a yearly $0.50^{\circ} \mathrm{C}$ more average module temperature than monocrystalline. Non-crystalline amorphous modules got a yearly $0.83^{\circ} \mathrm{C}$ more average temperature than thin film modules. The attainment and release of module temperature was related with material properties of PV module technologies. The amorphous module gave $5.7 \%, 2.7 \%$ and $15.0 \%$ more yearly average opencircuit voltage than polycrystalline, monocrystalline and thin film modules. Besides that, the thin film modules gave $6.5 \%$ and $1.7 \%, 9.3 \%$ and $4.0 \%$, and $11.3 \%$ and $8.8 \%$ more yearly average normalized short-circuit current and power output than polycrystalline, monocrystalline and thin film modules respectively. It was shown that the maximum annual average open-circuit voltage was given by amorphous modules and maximum short-circuit current and power output by thin film modules during the study period.
\end{abstract}

Keywords-climatic conditions; module temperature; IV characteristics

\section{INTRODUCTION}

Solar PV systems produce electricity by converting sunlight directly into electricity. PV modules are normally connected in series and in parallel to produce the desired voltage and current [1-3]. Each PV module is rated under standard test conditions [4-5] and such conditions could not be maintained in outdoor environments [6-7]. The power output (I-V, current-voltage) of modules is influenced by the intensity of solar radiation and module temperature [8]. Module temperature is one of the most important parameters responsible for deteriorating and reducing its power output $[8,9-10]$. PV modules give their maximum performance in cold climates and sunny skies rather than cloudy and hot climates [11]. In general, the efficiency of a PV module decreases [12] by $0.2 \% /{ }^{\circ} \mathrm{C}-0.5 \% /{ }^{\circ} \mathrm{C}$ rise in ambient temperature beyond nominal cell operating temperature [13]. Authors in [14] concluded that monocrystalline modules were found more efficient than polycrystalline and amorphous in January during high radiation conditions, and amorphous showed higher average performance ratio in low irradiance. Authors in [15] reported that the efficiency of GaAs/Ge cells was $9.47 \%$ when they were exposed to the sun light at an air mass of 1.5 and at $26.85^{\circ} \mathrm{C}$. Authors in [16] presented the PV systems and net metering in Greece. Authors in [17] improved the efficiency of PV and thermal systems by reducing the solar cell temperature from $51^{\circ} \mathrm{C}$ to $33^{\circ} \mathrm{C}$ by increasing wind velocity from $0.5 \mathrm{~m} / \mathrm{s}$ to $3 \mathrm{~m} / \mathrm{s}$. Authors in [18] stated that the I$\mathrm{V}$ characteristics of PV modules depend on the intensity of solar radiation. Authors in [19] analyzed the climatic data of two different cities namely Nawabshah and Quatta, Pakistan. Authors in [20] analyzed the electrical characteristics of polycrystalline, monocrystalline, amorphous, and thin film PV modules at 8:00, 12:00 and 16:00 hours from April to June 2016, and found that the polycrystalline module performed better than the others. This analysis was performed for a period of only three months, whereas the performance of modules requires to be examined for the entire year. Therefore, this study was conducted to determine the impact of module temperature on the electrical characteristics of PV modules for an entire year.

\section{MATERIALS AND METHODS}

Four commercially available PV module technologies were investigated in the climate of Nawabshah, Pakistan. The PV modules were fixed to south at an angle of $12^{\circ}$ with respect to the horizon. The experimental setup is shown in Figure 1 and the specifications of the examined PV technologies are given in Table I. The basic climatic variables were measured with the help of a professional weather station HP-2000. The electrical characteristic and module operating temperatures (surface and backside) of each PV module were recorded through Prova-210 and Prova-830. A total of eight k-type thermocouples were used for the recording of modules' temperature. To obtain sufficient outcomes, the data were recorded from November 2015 to October 2016. Furthermore, data loggers were connected with a computer for storing and further analyzing the data $[20,21]$. The average module temperature is considered as [20-22]: 


$$
T_{m}=\left(\frac{T_{s}+T_{b s}}{2}\right)
$$

where, $T_{m}$ is module temperature, $T_{s}$ and $T_{b s}$ are surface and backside module temperature.

Equation (2) is used to normalize the measured electrical characteristics values (ECVs) of four modules for comparison and performance analysis $[14,20]$ :

$$
\text { Output }=\left(\frac{E C V S_{(\text {measured })}}{E C V S_{(S T C)}}\right) \times 100
$$

where, STC is the standard test conditions.

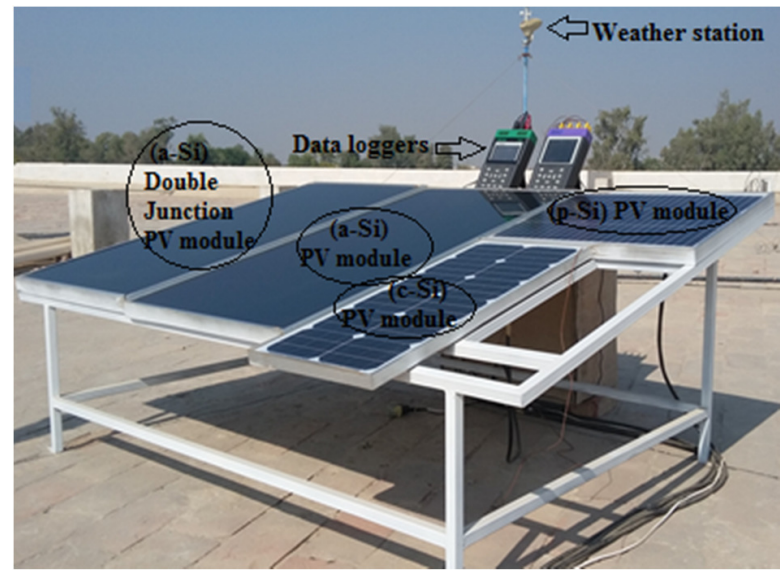

Fig. 1. Experimental setup

TABLE I. ELECTRICAL CHARACTERISTICS OF PV MODULES [20, 21]

\begin{tabular}{|c|c|c|c|c|c|}
\hline \multirow{2}{*}{$\begin{array}{c}\text { Module } \\
\text { parameters }\end{array}$} & Unit & \multicolumn{4}{|c|}{ Module Technologies } \\
\cline { 2 - 6 } Model & & $\mathbf{( p - S i )}$ & $\mathbf{( m - S i )}$ & $\mathbf{( a - S i )}$ & Thin film \\
\hline $\mathrm{V}_{\mathrm{oc}}$ & $\mathrm{V}$ & $\begin{array}{c}\text { SUN } \\
\mathbf{4 0 P}\end{array}$ & $\begin{array}{c}\text { SUN } \\
\mathbf{4 0 M}\end{array}$ & $\mathbf{T P S} 40$ & GS 50 \\
\hline $\mathrm{I}_{\mathrm{sc}}$ & $\mathrm{A}$ & 1.29 & 21.50 & 29.00 & 62.00 \\
\hline $\mathrm{V}_{\max }$ & $\mathrm{V}$ & 35.00 & 17.50 & 18.00 & 43.00 \\
\hline $\mathrm{I}_{\max }$ & $\mathrm{A}$ & 1.14 & 2.29 & 2.20 & 1.17 \\
\hline $\mathrm{P}_{\max }$ & $\mathrm{W}$ & 40.00 & 40.00 & 40.00 & 50.00 \\
\hline Area & $\mathrm{m}^{2}$ & 0.27 & 0.24 & 0.76 & 0.74 \\
\hline
\end{tabular}

\section{RESULTS AND DISCUSSION}

\section{A. Basic Climatic Variables}

Figure 2 demonstrates the hourly average values of global solar radiation $\left(\mathrm{G}_{\mathrm{sr}}\right)$, ambient temperature $\left(\mathrm{T}_{\mathrm{a}}\right)$, wind speed $\left(\mathrm{W}_{\mathrm{v}}\right)$ and relative humidity $\left(\mathrm{R}_{\mathrm{h}}\right)$. The yearly average values of $\mathrm{G}_{\mathrm{sr}}, \mathrm{T}_{\mathrm{a}}, \mathrm{W}_{\mathrm{v}}$ and $\mathrm{R}_{\mathrm{h}}$ were found $518.69 \mathrm{~W} / \mathrm{m}^{2}, 30.11^{\circ} \mathrm{C}, 2.14 \mathrm{~m} / \mathrm{s}$ and $42.66 \%$. It was noted that $\mathrm{G}_{\mathrm{sr}}$ and $\mathrm{T}_{\mathrm{a}}$ were rising from morning until noon, and then were decreasing gradually until the evening. The level of $R_{h}$ was more when $T_{a}$ was low, and vice versa. It is deduced that the $R_{h}$ is inversely proportional to the intensity of $\mathrm{G}_{\mathrm{sr}}$ and $\mathrm{T}_{\mathrm{a}}$ during the study period in outdoor conditions.

\section{B. Operating Module Temperature}

The operating temperature of each PV module $\left(\mathrm{T}_{\mathrm{m}}\right)$ during the study period is illustrated in Figure 3. The average PV module temperatures of polycrystalline, monocrystalline, amorphous and thin film modules were $43.96^{\circ} \mathrm{C}, 43.46^{\circ} \mathrm{C}$, $44.38^{\circ} \mathrm{C}$, and $43.55^{\circ} \mathrm{C}$ respectively. In comparison of crystalline modules, polycrystalline gained $0.50^{\circ} \mathrm{C}$ more yearly average temperature monocrystalline. By matching noncrystalline modules, the amorphous got $0.83^{\circ} \mathrm{C}$ more yearly average temperature than thin film modules. In general, it was observed that the polycrystalline module warms-up quickly in the morning, before noon, and attains more temperature between 07:00 and 11:00. Amorphous module gains lightly more temperature from 07:00 to 14:00 than the other modules until the evening. Thin film modules reached and released temperature more slowly than the other PV modules. The attainment and release of module temperature is directly related with the material properties of PV module technologies.

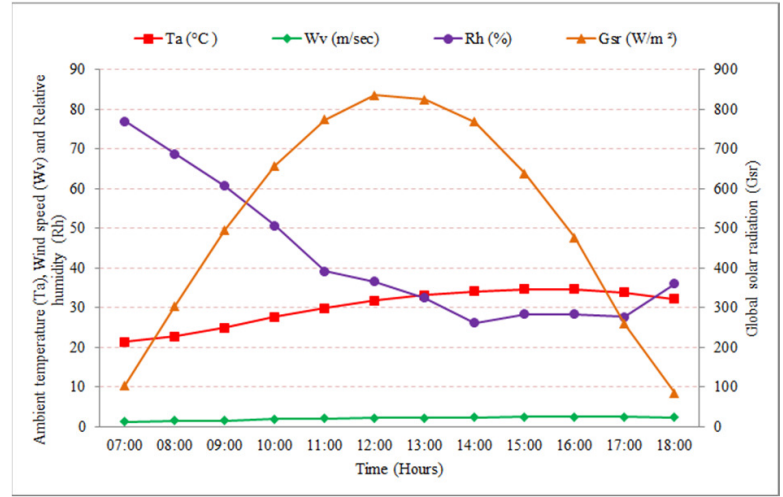

Fig. 2. Yearly hourly average climatic condition

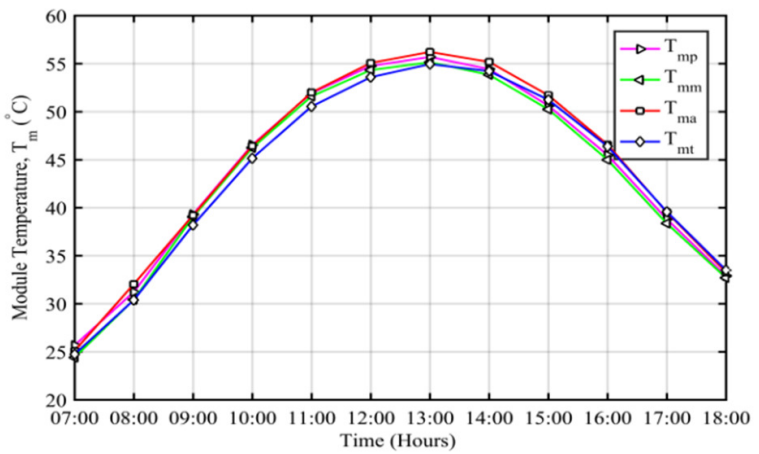

Fig. 3. Hourly average module temperatures.

\section{Electrical Characteristics}

The electrical characteristics, namely open-circuit voltage $\left(\mathrm{V}_{\mathrm{oc}}\right)$, short-circuit current $\left(\mathrm{I}_{\mathrm{sc}}\right)$, and power output $(\mathrm{P})$ of the four modules were recorded and analyzed. The results of current-voltage (I-V) and power-voltage (P-V) characteristics of polycrystalline are given in Figures 4 and 5. Maximum and minimum hourly average $\mathrm{V}_{\text {oc }}$ of polycrystalline were reported as $94.00 \%$ at 9:00 hours and $66.39 \%$ at 18:00 hours. The yearly average $\mathrm{V}_{\text {oc }}$ was $89.05 \%$. Similarly, maximum and minimum hourly average $\mathrm{I}_{\mathrm{sc}}$ was found $82.44 \%$ at $12: 00$ and $4.86 \%$ at 
18:00, and the yearly average $\mathrm{I}_{\mathrm{sc}}$ was $47.40 \%$. Maximum and minimum hourly average power (P) was $74.87 \%$ at $12: 00$ and $4.27 \%$ at $18: 00$, whereas, the yearly average power output $(\mathrm{P})$ was $43.97 \%$.

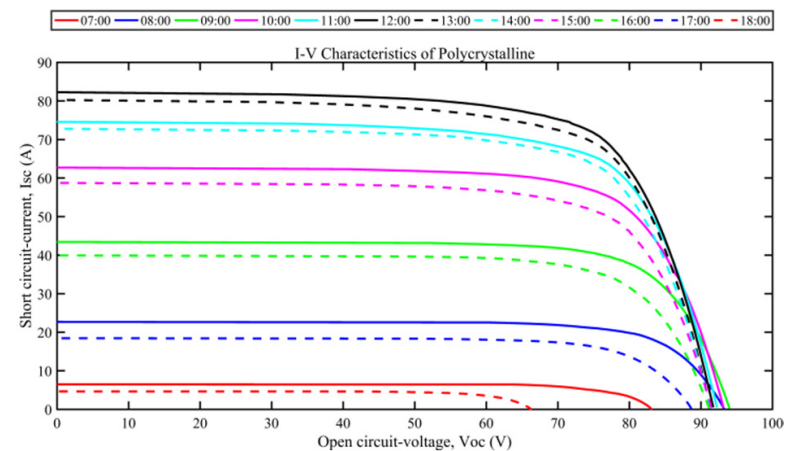

Fig. 4. Current-voltage of the polycrystalline module

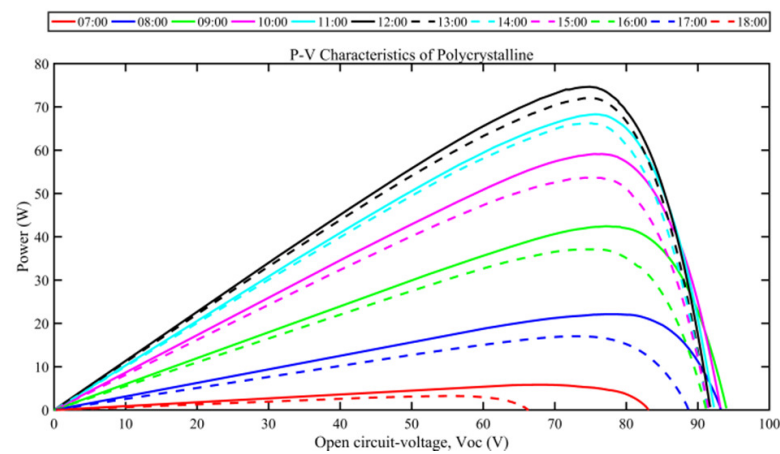

Fig. 5. Power-voltage of the polycrystalline module.

The yearly hourly average recorded values of $\mathrm{V}_{\mathrm{oc}}, \mathrm{I}_{\mathrm{sc}}$ and power output of monocrystalline are shown in Figures 6 and 7 . Maximum and minimum hourly average $\mathrm{V}_{\mathrm{oc}}$ of monocrystalline was $96.87 \%$ at $09: 00$ hours and $69.29 \%$ at 18:00 hours. The yearly average $\mathrm{V}_{\text {oc }}$ was $92.07 \%$. Similarly, the maximum and minimum hourly average $\mathrm{I}_{\mathrm{sc}}$ was $76.71 \%$ at $12: 00$ and $4.20 \%$ at $18: 00$, and the yearly average $I_{s c}$ was $44.57 \%$. Maximum and minimum hourly average power $(\mathrm{P})$ was $69.64 \%$ at $12: 00$ and $3.84 \%$ at $18: 00$. The yearly average power output $(\mathrm{P})$ was $41.61 \%$. The average results of I-V and $\mathrm{P}-\mathrm{V}$ characteristics of amorphous modules are given in Figures 8 and 9. Maximum and minimum hourly average $V_{o c}$ of amorphous PVs were $100.27 \%$ at $09: 00$ and $68.17 \%$ at 18:00. The yearly average $\mathrm{V}_{\text {oc }}$ was $94.73 \%$. Maximum and minimum hourly average $\mathrm{I}_{\mathrm{sc}}$ was $74.65 \%$ at $12: 00$ and $3.63 \%$ at $18: 00$, and the yearly average $\mathrm{I}_{\mathrm{sc}}$ was $42.57 \%$. Maximum and minimum hourly average power (P) was $62.24 \%$ at $12: 00$ and $3.27 \%$ at $18: 00$. The yearly average $\mathrm{P}$ output of the amorphous module was $36.79 \%$. The average values of $\mathrm{V}_{\mathrm{oc}}, \mathrm{I}_{\mathrm{sc}}$ and $\mathrm{P}$ of the thin film module are presented in Figures 10 and 11. Its maximum and minimum hourly average $\mathrm{V}_{\text {oc }}$ were $85.55 \%$ at 09:00 and $54.26 \%$ at 18:00. Its yearly average $\mathrm{V}_{\text {oc }}$ was $79.75 \%$. Maximum and minimum hourly average $\mathrm{I}_{\mathrm{sc}}$ were $94.75 \%$ at $12: 00$ and $4.24 \%$ at $18: 00$, and the yearly average $I_{\mathrm{sc}}$ was $53.85 \%$. Maximum and minimum hourly average $\mathrm{P}$ was
$78.89 \%$ at $12: 00$ and $3.62 \%$ at $18: 00$. The yearly average $\mathrm{P}$ output of the amorphous module was $45.62 \%$.

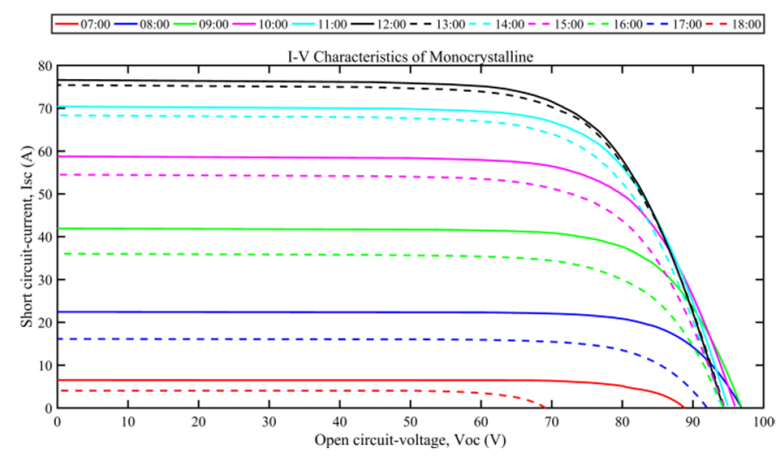

Fig. 6. Current-voltage of the monocrystalline module

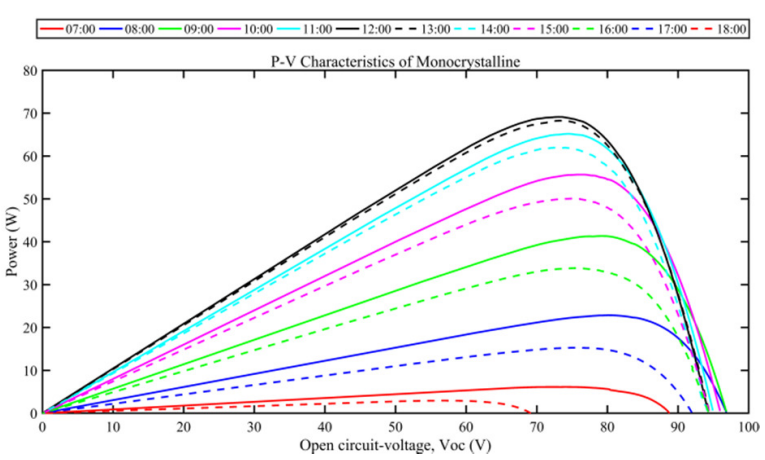

Fig. 7. Power-voltage of the monocrystalline module

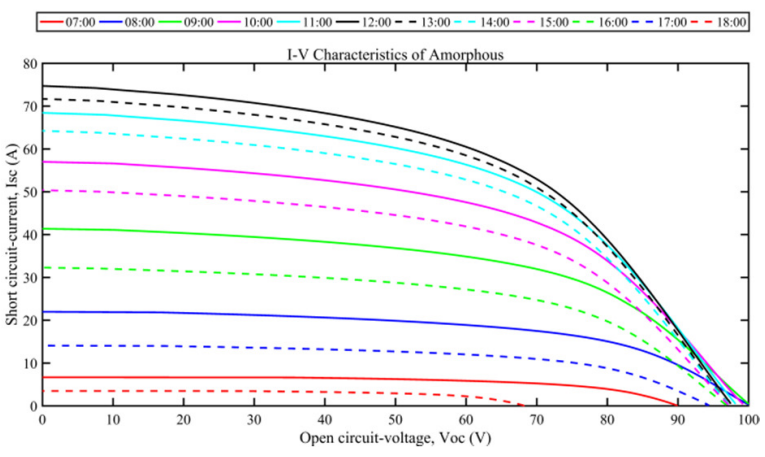

Fig. 8. Current-voltage of the amorphous module

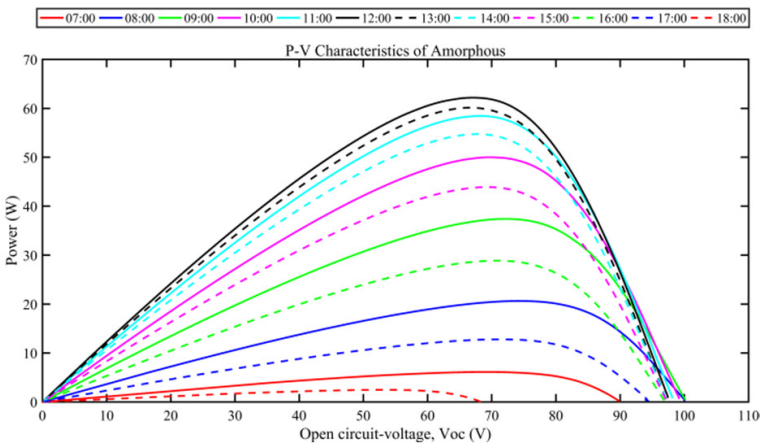

Fig. 9. Power-voltage of the amorphous module 


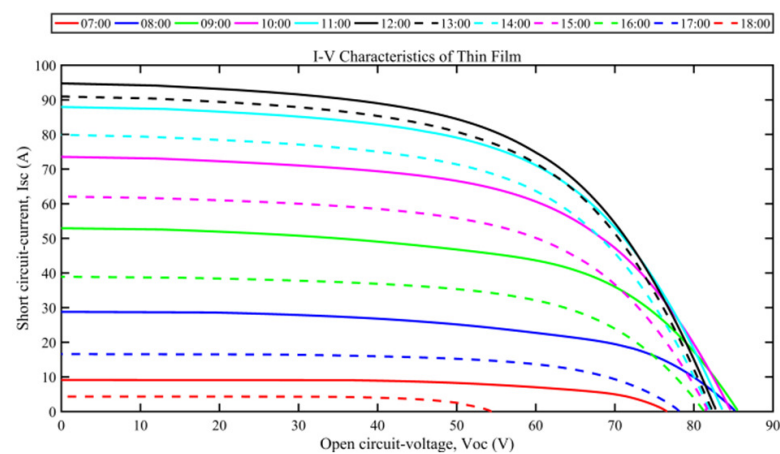

Fig. 10. Current-voltage of the thinfilm module

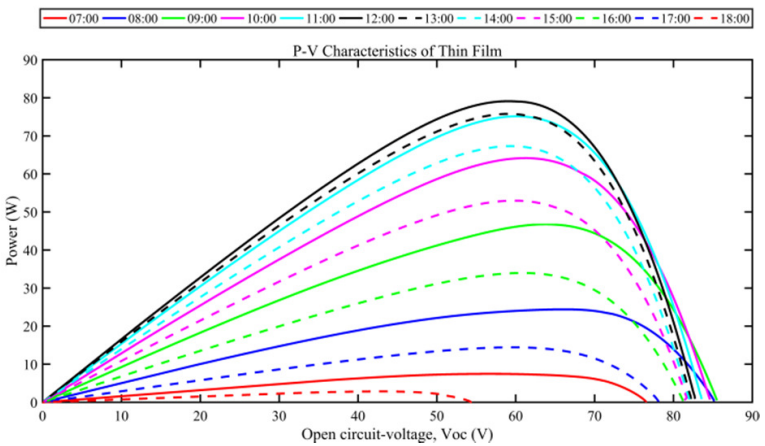

Fig. 11. Power-voltage of the thin film module

It was found that the amorphous PV module gave 5.68\%, $2.66 \%$ and $14.98 \%$ more yearly average $V_{o c}$ than polycrystalline, monocrystalline and thin film modules. Besides that, the thin film PV module gave $6.45 \%$ and $1.65 \%$, $9.28 \%$ and $4.01 \%$, and $11.28 \%$ and $8.83 \%$ more yearly average normalized $\mathrm{I}_{\mathrm{sc}}$ and power output values than polycrystalline, monocrystalline and thin film respectively. Maximum yearly average $V_{o c}$ was noted from amorphous module, and both $I_{s c}$ and $\mathrm{P}$ from the thin film module. In general, at higher global solar radiations, each PV module generated more $\mathrm{I}_{\mathrm{sc}}$ and gave more power output and vice versa. The voltage outputs were found inversely proportional to module and ambient temperature. It was found that $V_{\mathrm{oc}}$ was dropping and $\mathrm{I}_{\mathrm{sc}}$ was slightly increasing when module temperature was rising from standard test conditions.

\section{CONCLUSION}

In this research, the electrical characteristics of four commercially available PV module technologies were analyzed in the real climatic conditions of Nawabshah, Pakistan. During the experimental work, the average global solar radiation was $519 \mathrm{~W} / \mathrm{m}^{2}$, the ambient temperature was $30.1^{\circ} \mathrm{C}$, the wind speed was $2.1 \mathrm{~m} / \mathrm{s}$, and the relative humidity was $42.7 \%$. Polycrystalline, monocrystalline, amorphous and thin film modules exhibited $44.0^{\circ} \mathrm{C}, 43.5^{\circ} \mathrm{C}, 44.4^{\circ} \mathrm{C}$, and $43.6^{\circ} \mathrm{C}$ average module temperature respectively. Regarding crystalline modules, polycrystalline gained $0.50^{\circ} \mathrm{C}$ more yearly average temperature than monocrystalline. Regarding non-crystalline modules, the amorphous got $0.83^{\circ} \mathrm{C}$ more yearly average temperature than thin film. In general, thin film modules accumulated and released temperature slower than the other PV modules. The yearly average $\mathrm{V}_{\mathrm{oc}}, \mathrm{I}_{\mathrm{sc}}$ and power output were $89.05 \%, 47.40 \%$ and $43.97 \%$ for polycrystalline, $92.07 \%$, $44.57 \%$ and $41.61 \%$ for monocrystalline, $94.73 \%, 42.57 \%$ and $36.79 \%$ for amorphous, and $79.75 \%, 53.85 \%$ and $45.62 \%$ for thin film respectively. The amorphous module gave $5.7 \%$, $2.7 \%$ and $15.0 \%$ more yearly average $\mathrm{V}_{\mathrm{oc}}$ than polycrystalline, monocrystalline and thin film modules. Besides that, the thin film module gave $6.5 \%$ and $1.7 \%, 9.3 \%$ and $4.0 \%$, and $11.3 \%$ and $8.8 \%$ more yearly average normalized $\mathrm{I}_{\mathrm{sc}}$ and power output values than polycrystalline, monocrystalline and thin film respectively.

It was concluded that maximum yearly average $V_{\text {oc }}$ was given by amorphous and maximum $\mathrm{I}_{\mathrm{sc}}$ and power output by thin film modules during the study period. All PV modules generated more $\mathrm{I}_{\mathrm{sc}}$ and gave more power output at higher level of solar radiation. The voltage outputs of the PV modules were found inversely proportional to both module and ambient temperature.

\section{REFERENCES}

[1] S. A. Kalogirou, Solar Energy Engineering: Processes and Systems, Academic Press, 2014

[2] J. A. Duffie, W. A. Beckman, Solar Engineering of Thermal Processes, Wiley, 2013

[3] S. R. Shakeel, J. Takala, W. Shakeel, "Renewable energy sources in power generation in Pakistan", Renewable and Sustainable Energy Reviews, Vol. 64, pp. 421-434, 2016

[4] A. Q. Jakhrani, S. R. Samo, S. A. Kamboh, J. Labadin, A. R. H. Rigit, "An improved mathematical model for computing power output of solar photovoltaic modules", International Journal of Photoenergy, Vol. 2014, Article ID 346704, 2014

[5] E. Skoplaki, J. A. Palyvos, "On the temperature dependence of photovoltaic module electrical performance: A review of efficiency/power correlations", Solar Energy, Vol. 83, No. 5, pp. 614624, 2009

[6] A. Ibrahim, "Analysis of electrical characteristics of photovoltaic single crystal silicon solar cells at outdoor measurements", Smart Grid and Renewable Energy, Vol. 2, pp. 169-175, 2011

[7] A. Q. Malik, S. J. B. H. Damit, "Outdoor testing of single crystal silicon solar cells", Renewable Energy, Vol. 28, No. 9, pp. 1433-1445, 2003

[8] A. Q. Jakhrani, A. K. Othman, A. R. H. Rigit, S. R. Samo, "Determination and comparison of different photovoltaic module temperature models for Kuching, Sarawak", IEEE Conference on Clean Energy and Technology, Kuala Lumpur, Malaysia, June 27-29, 2011

[9] Y. Du, C. J. Fell, B. Duck, D. Chen, K. Liffman, Y. Zhang, M. Gu, Y. Zhu, "Evaluation of photovoltaic panel temperature in realistic scenarios", Energy Conversion and Management, Vol. 108, pp. 60-67, 2016

[10] E. Skoplaki, A. G. Boudouvis, J. A. Palyvos, "A simple correlation for the operating temperature of photovoltaic modules of arbitrary mounting", Solar Energy Materials and Solar Cells, Vol. 92, No. 11, pp. 1393-1402, 2008

[11] P. Arjyadhara, S. M. Ali, J. Chitralekha, "Analysis of solar PV cell performance with changing irradiance and temperature", International Journal of Engineering and Computer Science, Vol. 2, No. 1, pp. 214220, 2013

[12] T. Yamaguchi, M. Kawakami, K. Kitano, S. Nakagawa, T. Tokoro, T. Nakano, H. Ohyama, "Data analysis on performance of PV system installed in south and north directions", IEEE 3rd World Conference on Photovoltaic Energy Conversion, 2003, Osaka, Japan, May 11-18, 2003

[13] V. Eveloy, P. Rodgers, S. Bojanampati, "Enhancement of photovoltaic solar module performance for power generation in the Middle East", 28th IEEE Annual Semiconductor Thermal Measurement and Management Symposium, San Jose, USA, March 18-22, 2012 
[14] M. A. Bashir, H. M. Ali, S. Khalil, M. Ali, A. M. Siddiqui, "Comparison of performance measurements of photovoltaic modules during winter months in Taxila, Pakistan", International Journal of Photoenergy, Vol. 2014, Article ID 898414, 2014

[15] S. E. T. Moghaddam, S. M. Kankanani, "Numerical simulation of a mechanically stacked GaAs/Ge solar cell”, Engineering, Technology \& Applied Science Research, Vol. 7, No. 3, pp. 1611-1614, 2017

[16] F. Mavromatakis, G. Viskadouros, H. Haritaki, G. Xanthos, "Photovoltaic systems and net metering in Greece", Engineering, Technology \& Applied Science Research, Vol. 8, No. 4, pp. 3168-3171, 2018

[17] P. Salami, Y. Ajabshirchi, S. Abdollahpoor, H. Behfar, “A comparison among different parameters for the design of a photovoltaic/thermal system using computational fluid dynamics", Engineering, Technology \& Applied Science Research, Vol. 6, No. 5, pp. 1119-1123, 2016

[18] M. Sojoudi, R. Madatov, T. Sojoudi, P. Farhadi, "Achieving steady and stable energy from AlGaAsGaAs solar cells", Engineering, Technology \& Applied Science Research, Vol. 1, No. 6, pp. 151-154, 2011

[19] A. Q. Jakhrani, A. R. Jatoi, M. M. Jakhrani, A. N. Laghari, S. A. Kamboh, "Appraisal of climatic conditions for potential solar energy applications in Nawabshah and Quetta Cities", Engineering, Technology \& Applied Science Research, Vol. 9, No. 1, pp. 3711-3714, 2019

[20] A. R. Jatoi, S. R. Samo, A. Q. Jakhrani, "Influence of Temperature on Electrical Characteristics of Different Photovoltaic Module Technologies", International Journal of Renewable Energy Development, Vol. 7, No. 2, pp. 85-91, 2018

[21] A. R. Jatoi, S. R. Samo, A. Q. Jakhrani, "Influence of ambient temperature and solar radiations on photovoltaic module's temperature and power output", International Journal of Natural and Engineering Science, Vol. 10, No. 2, pp. 43-47, 2016

[22] B. J. Huang, P. E. Yang, Y. P. Lin, B. Y. Lin, H. J. Chen, R. C. Lai, J. S. Cheng, "Solar cell junction temperature measurement of PV module", Solar Energy, Vol. 85, No. 2, pp. 388-392, 2011 